\title{
Age Related Change in Thyroid Function
}

\author{
Shakila Rahman ${ }^{1}$, Nasim Jahan ${ }^{2}$, Nayma Sultana ${ }^{3}$
}

\begin{abstract}
Background: Thyroid hormones play a vital role in metabolism, sensitivity of tissues to other hormones and also in oxygen consumption of almost all cells of the body. However, mild to moderate decrease in function of thyroid gland may occur with advancing age even in apparently healthy elderly subjects. Objectives: To observe age related change in thyroid function status in apparently healthy elderly subjects in Bangladesh. Methods: This cross sectional study was carried out in the Department of Physiology, Sir Salimullah Medical College, Dhaka between $1^{\text {st }}$ January 2011 and $31^{\text {st }}$ December 2011. Sixty apparently healthy elderly subjects of both sexes aged 50 to 75 years were taken as study group. They were collected from Probin Nibash Hitoishi Shangha, Agargaon, Dhaka. In addition, 30 apparently healthy young adult subjects aged 20-40 years were included as control. For assessment of thyroid function, serum free thyroxine $\left(\mathrm{FT}_{4}\right)$, free triiodothyronine $\left(\mathrm{FT}_{3}\right)$ and thyroid stimulating hormone (TSH) levels were estimated by ELISA method. Statistical analysis was done by one way ANOVA, Bonferroni test and Pearson's Correlation Coefficient test as applicable. Results: In this study, mean serum free thyroxine $\left(\mathrm{FT}_{4}\right)$ and free triiodothyronine $\left(\mathrm{FT}_{3}\right)$ levels were significantly $(\mathrm{p}<0.001)$ lower and serum thyroid stimulating hormone $(\mathrm{TSH})$ level was significantly $(\mathrm{p}<0.001)$ higher in apparently healthy elderly subjects in comparison to those of the healthy young subjects. Again, serum FT $_{4}$ and $\mathrm{FT}_{3}$ levels were negatively correlated whereas serum TSH level was positively correlated with age of the subjects. Conclusion: The present study revealed a progressive decrease in thyroid function with advancement of age.
\end{abstract}

Key words: Elderly, Thyroid, Free Thyroxine $\left(\mathrm{FT}_{4}\right)$, Free Triiodothyronine $\left(\mathrm{FT}_{3}\right)$.

J Bangladesh Soc Physiol. 2012 December; 7(2): 72-77

For Authors Affiliation, see end of text.

http://www.banglajol.info/index.php/JBSP

\begin{abstract}
Introduction
Aging (or senescence) is a physiological process which is characterized by a progressive generalized impairment of many functions of the body resulting in the loss of adaptive responses to stress and a growing risk of age associated disease $^{1}$. However, after the age of 60 years a person is commonly known as old aged person, when it involves progressive loss of cells, reduced metabolic activities and decreased efficiency of many functions of different organs ${ }^{2}$.
\end{abstract}

Received: August 2012; Accepted : December 2012
Again, aging is not solely an intrinsic process, as it also occurs in the context of an individual's interaction with the environmental factors such as lack of exercise, poor diet, cigarette smoking, and heavy alcohol consumption. Moreover, genetic factor is also thought to play a role in causing physiological changes in aging process $^{1}$.

With the advancement of age, there is gradual decrease in body functions affecting cardiovascular, respiratory, renal, nervous as well as endocrine and metabolic systems ${ }^{3}$. These 
changes may alter hormone production, metabolism, biological activities, target tissue response to hormones and rhythms in the body such as the menstrual cycle ${ }^{4}$. In old age brain has diminished homeostatic reserve and is vulnerable to disturbances in the internal milieu ${ }^{5}$.

Apart from diabetes, thyroid dysfunction is a common endocrine disorder, especially in the elderly and is often associated with greater morbidity than in younger persons ${ }^{6}$. This thyroid dysfunction may occur due to alteration in the hypothalamo-pituitary-thyroid axis ${ }^{5}$. Thyroid function is determined by serum $\mathrm{T}_{4}, \mathrm{~T}_{3}$ and $\mathrm{TSH}$ levels. Among them TSH concentration may be the best discriminator between normal and mild excess, because serum TSH level reflects the status of thyroid axis much more sensitively than serum thyroid hormone levels ${ }^{7}$.

Thyroid dysfunction is defined as the altered serum thyroid stimulating hormone (TSH) level with normal or altered thyroid hormones, free thyroxine $\left(\mathrm{FT}_{4}\right)$ and free triiodothyronine $\left(\mathrm{FT}_{3}\right)$. Thyroid dysfunction is a common endocrine disorder affecting about 300 million people worldwide and over half are presumed to be unaware of their condition ${ }^{8}$. However, hypothyroidism increases in prevalence and incidence among the elderly of both sexes due to changes in the metabolic clearance of thyroid hormone, drug interactions and potential adverse reactions ${ }^{9}$. Hypothyroidism may produce bradycardia, decreased heart muscle strength, slow mentation, somnolence, increased CSF protein level, prolonged stretch reflexes, muscle weakness, cramps, muscle stiffness, hypercholesterolemia, diarrhea, yellowish tint of skin and altered level of hormonal secretion from other endocrine glands ${ }^{10}$. Thyroid diseases are frequent in older individuals and symptoms of hypothyroidism such as tiredness, fatigue, lack of concentration or dry skin can be very similar to complaints associated to aging ${ }^{11}$.
It has been observed that mean serum $\mathrm{T}_{3}$ level has declined in both male and female with their increasing age ${ }^{12}$. Similarly, some investigators observed that elderly population had a significantly lower mean serum $\mathrm{T}_{3}$ level than young individuals ${ }^{13}$. Some researchers found that mean serum $T_{4}$ values for male were stable throughout life. Again, serum $\mathrm{T}_{4}$ and $\mathrm{T}_{3}$ levels were found to be decreased and TSH level was increased progressively with age ${ }^{14}$. There is an increasing prevalence of high levels of thyroid stimulating hormone (TSH) with increasing age particularly in postmenopausal women which are even higher than men ${ }^{15}$.

Alteration in the hypothalamic-pituitary-thyroid axis in elderly is usually associated to psychiatric problems which include mood disturbances, anxiety, cognitive dysfunction, delirium, dementia, Alzheimer's disease and neuropathology ${ }^{16}$. The incidence of hypothyroidism increases predominantly among the healthy elderly persons. Physiological changes in thyroid hormone concentration might be related to the changes in the overall physical functions in the elderly. Some studies have been done on this regard in abroad but no such published data has yet been available on this aspect in our country. Therefore, the present study has been designed to observe some aspects of thyroid function status in healthy elderly subjects. It is expected that the findings of this study would help the physician for early detection and better management of thyroid dysfunction in elderly persons in order to improve their quality of life and also to develop awareness among the general people.

\section{Methods}

This cross sectional study was carried out in the Department of Physiology, Sir Salimullah Medical

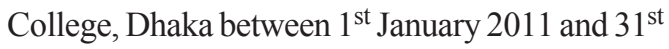
December 2011. Study subjects were selected by following simple random sampling procedure and 
the protocol of this study was approved by Institutional Ethics Committee (IEC) of Sir Salimullah Medical College. Sixty apparently healthy elderly subjects of both sexes aged 50 to 75 years were taken as study group and was further divided into middle age group (group B, age $50-60$ years, $n=30$ ) and extreme age group (group $\mathrm{C}$, age $61-75$ years, $\mathrm{n}=30$ ). In addition, 30 apparently healthy young adult subjects aged 20-40 years were included as control (group A, young age group). All the apparently healthy elderly subjects were selected from Probin Nibash Hitoishi Shangha, Agargaon, Dhaka and healthy young subjects were selected from personal contact. For assessment of thyroid function, serum free thyroxine $\left(\mathrm{FT}_{4}\right)^{17}$, free triiodothyronine $\left(\mathrm{FT}_{3}\right)^{17}$ and thyroid stimulating hormone (TSH) $)^{18}$ levels were estimated by enzyme linked immunosorbant assay (ELISA) method. Statistical analysis was done by one way ANOVA, Bonferroni test and Pearson's Correlation Coefficient tests as applicable and $\mathrm{p}$ value $<0.05$ was considered as significant.

\section{Results}

The mean serum $\mathrm{FT}_{4}$ and $\mathrm{FT}_{3}$ levels were significantly $(\mathrm{p}<0.001)$ lower, whereas mean serum TSH level was significantly $(p<0.001)$ higher in middle (Group-B) and extreme age group (Group-C) in comparison to those of young age group (Group-A). Whereas, these levels were almost similar and showed no statistically significant differences between middle (Group-B) and extreme age group (GroupC) (Table I).

Serum free thyroxine $\left(\mathrm{FT}_{4}\right)(\mathrm{r}=-0.538)$ and free triiodothyronine $\left(\mathrm{FT}_{3}\right)(\mathrm{r}=-0.458)$ levels were negatively correlated and thyroid stimulating hormone (TSH) level was positively correlated ( $\mathrm{r}$ $=0.418)$ with different age and these relationships were statistically significant $(\mathrm{p}<0.001)$ (Figure 1, 2 and 3).
Table I: Serum free thyroxine $\left(\mathrm{FT}_{4}\right)$, free triiodothyronine $\left(\mathrm{FT}_{3}\right)$ and thyroid stimulating hormone (TSH) levels in different groups $(\mathrm{n}=90)$

\begin{tabular}{lccc}
\hline Groups & $\begin{array}{c}\mathrm{FT}_{4} \\
(\rho \mathrm{mol} / \mathrm{L})\end{array}$ & $\begin{array}{c}\mathrm{FT}_{3} \\
(\rho \mathrm{\rho mol} / \mathrm{L})\end{array}$ & $\begin{array}{c}\mathrm{TSH} \\
(\mu \mathrm{IU} / \mathrm{ml})\end{array}$ \\
\hline $\mathrm{A}(\mathrm{n}=30)$ & $12.87 \pm 2.25$ & $4.53 \pm 1.00$ & $0.98 \pm 0.49$ \\
& $(10.53-17.30)$ & $(3.50-6.88)$ & $(0.430-2.370)$ \\
$\mathrm{B}(\mathrm{n}=30)$ & $10.56 \pm 2.33$ & $3.56 \pm 1.08$ & $2.05 \pm 1.42$ \\
& $(6.12-16.95)$ & $(2.10-4.98)$ & $(0.783-6.515)$ \\
$\mathrm{C}(\mathrm{n}=30)$ & $9.62 \pm 1.97$ & $3.31 \pm 1.10$ & $2.36 \pm 1.62$ \\
& $(6.28-14.83)$ & $(1.18-5.66)$ & $(0.929-7.592)$ \\
\hline Sroups & $\mathrm{FT}_{4}$ & $\mathrm{FT}_{3}$ & $\mathrm{TSH}$ \\
& $(\mathrm{p}$ value $)$ & $(\mathrm{p}$ value $)$ & $(\mathrm{p}$ value $)$ \\
\hline A vs B & $0.000^{* * *}$ & $0.002^{* *}$ & $0.005^{* *}$ \\
A vs C & $0.000^{* * *}$ & $0.000^{* * *}$ & $0.000^{* * *}$ \\
B vs C & $0.295^{\mathrm{ns}}$ & $1.000^{\mathrm{ns}}$ & $1.000^{\mathrm{ns}}$ \\
\hline
\end{tabular}

Data are expressed as mean \pm SD. For statistical analysis one way ANOVA was performed for comparison among the groups and Bonferroni test was done to compare between two groups. Figures in parentheses indicate ranges.

Group A: Apparently healthy young adult subjects (Young age group, 20-40 years)

Group B: Apparently healthy elderly subjects (Middle age group, 50-60 years)

Group C: Apparently healthy elderly subjects (Extreme age group, 61-75 years)

$$
\begin{array}{ll}
* * * & =\mathrm{p}<0.001 \\
* * & =\mathrm{p}<0.01 \\
\mathrm{~ns} & =\text { non significant }(\mathrm{p}>0.05) \\
\mathrm{n} & =\text { number of subjects }
\end{array}
$$




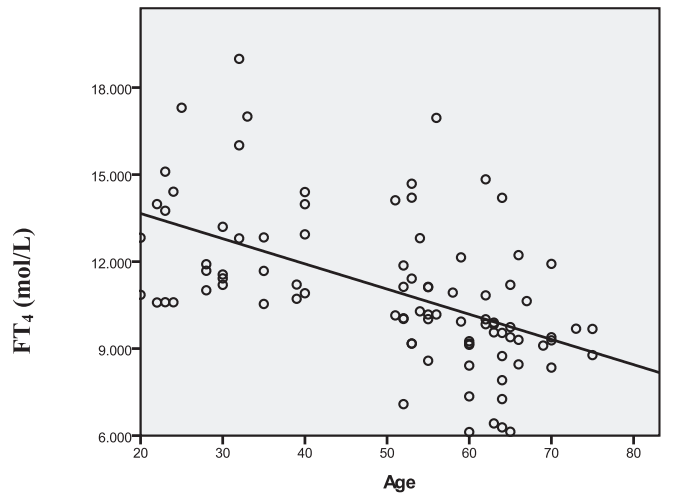

Age (Years)

Figure 1: Correlation of serum free thyroxine $\left(\mathrm{FT}_{4}\right)$ level with different ages $(\mathrm{n}=90)$

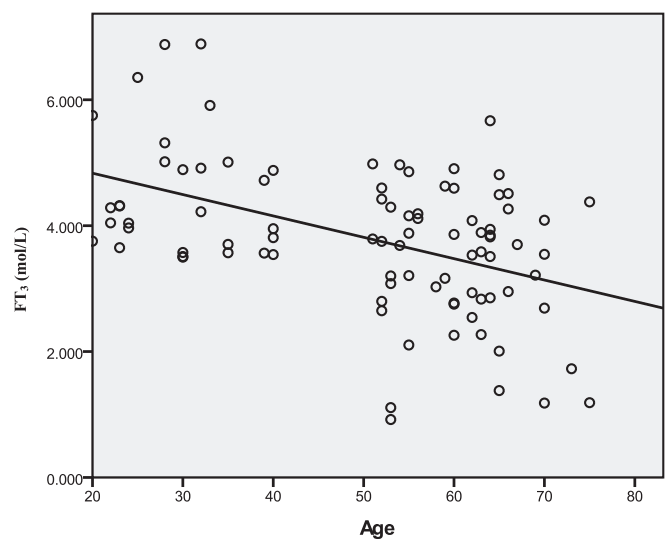

Figure 2: Correlation of serum free triiodothyronine $\left(\mathrm{FT}_{3}\right)$ level with different ages $(\mathrm{n}=90)$

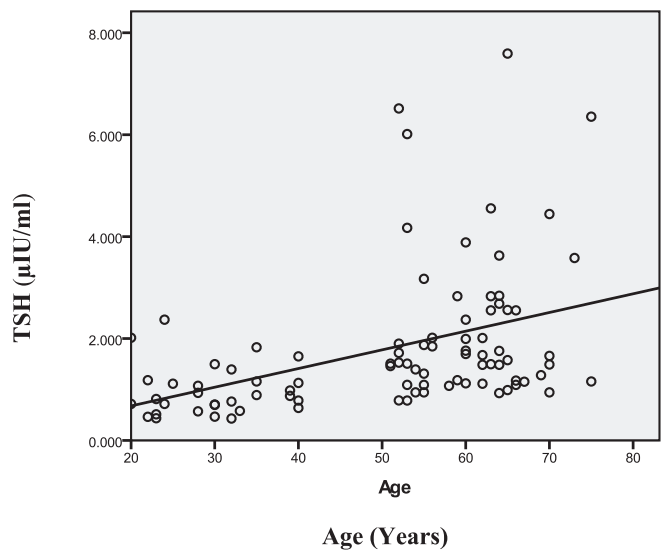

Figure 3: Correlation of serum thyroid stimulating hormone $(\mathrm{TSH})$ level with different ages $(\mathrm{n}=90)$

\section{Discussion}

In the present study, findings of thyroid function parameters and plasma proteins of young age group of subjects were almost within normal range and also similar to the published reports from different countries ${ }^{19,20}$.

In this study, significantly lower serum $\mathrm{FT}_{4}$ and $\mathrm{FT}_{3}$ levels with significantly higher TSH level indicate comparatively lower thyroid activity in healthy elderly subjects in comparison to those of young age group of subjects, which are similar to those findings reported by some researchers ${ }^{21}$. Again, in this study, these values were almost similar in both the elderly groups of subjects is also similar to the finding observed by other researchers ${ }^{14}$. On the contrary, some other researchers found a higher serum $\mathrm{FT}_{4}$ level in the elderly subjects especially after the age of 65 years ${ }^{22}$. Again, unaltered serum $\mathrm{FT}_{3}$ level in the subjects up to 80 years and then decreased progressively with advancing age of the subjects were observed by some investigators ${ }^{23}$. However, various research workers observed progressively decreased level of serum TSH with increasing age ${ }^{13,22}$. This inconsistence of the results may be due to higher age range of the study subjects and large sample size in their study.

Again, findings of significant negative correlation of serum free thyroxine $\left(\mathrm{FT}_{4}\right)$ and free triiodothyronine $\left(\mathrm{FT}_{3}\right)$ levels and positive correlation of serum thyroid stimulating hormone (TSH) level with different ages of the study subjects are suggesting decreased thyroid activity with aging process which is equivocal with some other investigators ${ }^{24}$. In another study $\mathrm{FT}_{4}$ and $\mathrm{FT}_{3}$ showed no significant relationship with aging process which was may be due to consistent degradation rate of the thyroid hormones with advancing age of the subjects ${ }^{20}$.

Many explanations are suggested by different investigators for the gradual decrease of serum thyroid hormone $\left(\mathrm{FT}_{4}\right.$ and $\left.\mathrm{FT}_{3}\right)$ levels with increasing age though the exact mechanism is 
not yet clear. This may be due to primary retardation of processes for hormone metabolism within the cell which is associated with aging process $^{12,25}$, increased degradation rate of thyroid hormones in old age ${ }^{26}$, age related decline of hepatic 52 -deiodinase activity that may reduce peripheral conversion of $T_{4}$ to $T_{3}$ which leads to lower level of $\mathrm{T}_{3}{ }^{27}$.

Some researchers suggested that, significant decrease in the transthyretin (TTR) concentration observed in the elderly subjects which may cause impairment of thyroid status with aging process ${ }^{28}$, age specific influence on the hypothalamo-pituitary-thyroid axis that may cause reduced level of serum free triiodothyronine $\left(\mathrm{FT}_{3}\right)$ in healthy elderly subjects by shifting the axis to a lower level of activity ${ }^{29}$.

In the present study, decreased thyroid function status was observed in apparently healthy elderly subjects age ranged from 50 to 75 years as the measured value of serum $\mathrm{FT}_{4}$ and $\mathrm{FT}_{3}$ were lower. However, increased degradation of thyroid hormone with aging process may be responsible for their decreased level in the elderly subjects of the present study. Again, this effect, was more pronounced in the subjects of extreme age group (61 to 75 years) indicating a progressive declination of thyroid hormone with aging process. The negative correlations of serum $\mathrm{FT}_{4}$ and $\mathrm{FT}_{3}$ levels with aging of the subjects are in favor of these findings.

\section{Conclusion}

From this study, it can be concluded that, progressive decreased in thyroid function can occur with aging process, which is characterized by lower levels of serum $\mathrm{FT}_{4}$ and $\mathrm{FT}_{3}$ and higher level of serum TSH.

\section{Acknowledgement}

Authors of this study acknowledge the partial financial support from the research grant of DGHS of Bangladesh. The authors are also thankful to the study subjects for their active, sincere and voluntary participation.

\section{Author affiliations}

1. *Shakila Rahman, Assistant Professor, Department of Physiology, City Medical College, Gazipur, Dhaka. Email: shakila.ssmc@gmail.com

2. Nasim Jahan, Professor \& Head, Department of Physiology, Sir Salimullah Medical College SSMC, Mitford, Dhaka. Email: prof.dr.nasimjahan@ gmail.com

3. Nayma Sultana, Associate Professor, Department of Physiology, Sir Salimullah Medical College SSMC, Mitford, Dhaka. Email; nayma_sultana@yahoo.com

*for correspondence

\section{References}

1. Colledge NR, Walker BR, Ralston SH. Principal and Practice of Medicine, $21^{\text {st }}$ ed. Churchill Livingstone; 2010.

2. Gurav RV, Kartikeyan S. Problems of Geriatric Population in Urban Area BHJ. Available from: http://www.bhj.org/journal/2002 4401 jan/ org_47.htm

3. Rashid KM, Rahman M, Hyder S. Health of The Aged. Textbook of Community Medicine and Public Health, $4^{\text {th }}$ ed, RHM publishers, Dhaka 2008. 476482 .

4. Chase C. Factors that affect endocrine function. The Hormone Foundation 2011; 1-2.

5. Patil VW, Mujawar SA. The relationship between cortisol and thyroid function tests in geriatric patients with psychiatric disorder. Current Neurobiology 2010; 1(2): 133-135.

6. Helfand M, Crapo LM. Screening for thyroid disease. Ann Intern Med 1990; 112: 840-849.

7. Woeber KA. Subclinical thyroid dysfunction. Arch Intern Med 1997; 5: 69-73.

8. Peter PAS. Epidemiology of Thyroid dysfunctionhypothyroidism and hyperthyroidism. Thyroid International 2009; 2: 1-16.

9. Helfand M. Screening for subclinical thyroid dysfunction in nonpregnant adults: a summary of the evidence for the U.S. Preventive services Task Force. Ann Intern Med 2004; 140: 128-141.

10. Barrett KE, Barman SM, Boitano S, Brooks HL. Review of Medical Physiology, $23^{\text {rd }}$ ed. 2010; The McGraw - Hill Companies, India.

11. Bemben DA, Winn P, Hamm RM, Morgan L, Davis A, Barton E. Thyroid disease in the elderly. Part 1. Prevalence of undiagnosed hypothyroidism. J Fam Pract 1994; 38: 577-582. 
12. Lipson A, Nickoloff E, Hsu T, Kasecamp WR, Drew HM, Shakir R, Wanger HN. A study of age dependent changes in thyroid function tests in adults. The Journal of Nuclear Medicine 1979; 20(11): 1124-1130.

13. Munib F, Abbas HG, Khan MS, Naeem M, Hyder SW. Effect of age, Sex and Goiter on Thyroid Function Tests in Euthyroid Individuals Establishment of Norms of Lahore and Surrounding Areas. J. Chem. Soc. Pak. 2008; 30(5): 785-789.

14. Kaur G, Kalsotra L, Sadhoo AK. Age and sex related changes in thyroid functions in normal healthy subjects of Jammu region. JK SCIENCE 2007; 9 (3): $132-136$

15. Schindler AE. Thyroid function and postmenopause. Gynec Endocrinol 2003; 17(1): 79-85.

16. Bensenor IM, Lotufo PA, Menezes PR, Scazufca M. Subclinical hyperthyroidism and dementia: the Sao Paulo Ageing and Health Study (SPA). Bio Med Central 2010; 10(298): 1-8.

17. Boscato LM, Stuart MC. Incidence and specificity of interference in two site immunoassays. Clin Chem 1986; 32 (8): 1491.

18. Uotila M, Ruoslahti E, Engvall, E. Estimation of thyroid stimulating hormone. J Immunol Methods 1981; 42: 11-15.

19. Westgren $U$, Burger $A$, Ingemansson $S$, Melander A, Tibblin S, Wahlin E. Blood levels of 3,5,32 triiodothyronine and thyroxine: differences between children, adults and elderly subjects. Acta Med Scand 1976; 200(6): 493-495.

20. Sargent ME, Evola KL, Randall GK, Davdson J. Correlates of Protein Intake Among Community Dwelling Older Adults. Undergraduate Research Journal for the Human Sciences 2010; 9: 1-7.

21. Corsonello A, Montesanto A, Berardelli M, Rango FD, Dato S, Mari V, Mazzei B, Lattanzio F, Passarino G. A cross section analysis of $\mathrm{FT}_{3}$ agerelated changes in a group of old and oldest old subjects, including centenarians' relatives, shows that a down-regulated thyroid function has a familial component and is related to longevity. Age and Aging 2010; 39: 723-727.

22. Ceresini G, Lauretani F, Maggio M, Cead GP, Morganti S, Usberti E, Chezzi C, Valcavi R, Bandinelli S, Guralnik JM, Cappola AR, Valenti G, Ferrucci L. Thyroid function abnormalities and cognitive impairment in elderly people: results of the Invecchiare in Chianti study. J Am Geriatr Soc 2009; 57(1): 89-93.

23. Westgren U, Burger A, Ingemansson S, Melander A, Tibblin S, Wahlin E. Blood levels of 3,5,32 triiodothyronine and thyroxine: differences between children, adults and elderly subjects. Acta Med Scand 1976; 200(6): 493-495.

24. Feart C, Pallet V, Boucheron C, Higueret D, Alfos S, Letenneur L, Dartigues JF, Higueret P. Aging affects the retinoic mRNA expression in human peripheral blood mononuclear cells. European Journal of Endocrinology 2005; 152: 449-458.

25. Andersen S, Bruun NH, Pedersen KM, Laurberg, P. Biologic Variation is Important for Interpretation of Thyroid Function Tests. Mary Ann Liebert, Inc. - Thyroid 2003; 13 (11): 1069-1078.

26. Hesch RD, Gatz J, Pape J. Total and free triiodothyronine and thyroid binding globulin concentration in elderly human persons. Eur J Clin Invest 1976; 6: 139-145.

27. Panicker V, Saravanan P, Vaidya B. Common variation in the DIO2 gene predicts baseline psychological well-being and response to combination thyroxine plus triiodothyronine therapy in hypothyroid patients. J Clin Endocrinol Metab 2009; 94: 1623-1629.

28. Schreiber G. The evolutionary and integrative roles of transthyretin in thyroid hormone homeostasis. Journal of Endocrinology 2002; 175: 61-73.

29. Erfurth EMT, Hagmar LE. Decreased serum testosterone and free triiodothyronine levels in healthy middle aged men indicate an age effect at the pituitary level. Eur J Endocrinol 1995; 132: 663-667. 